\title{
Low Head Pico-Hydro: A Robust Rural Renewable Energy Technology for Remote Rural Areas
}

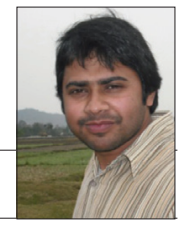

Biraj Gautam

Abstract: The rural electrification is the most needed pill for equitable economic and environmental development of Nepal. However, it comes with great challenges. The cost involved for grid extension, availability of power in grid and pre-condition required for alternate energy options for affordable rural energy supply significantly hinders the process of rural electrification. The low-head Pico-hydro is a promising technology which has positioned itself in a special niche of renewable energy technologies and is very important to address the problems Nepal is currently facing.

Key words: Low head Pico-hydro, reliable rural electrification, energy market, environmental sustainability

\section{Background}

Tany villages in Nepal have limited access 1 to energy resources that could improve their livelihoods. They are dependent on either firewood, which is time consuming to collect or depleting at an alarming rate or expensive oil imports which are beyond their means. The electrical grid connection is available to only $32.7 \%$ of the population (ISRC 2008). Its extension into remote rural locations is slow due to technical difficulties, and high cost and low per capita electricity

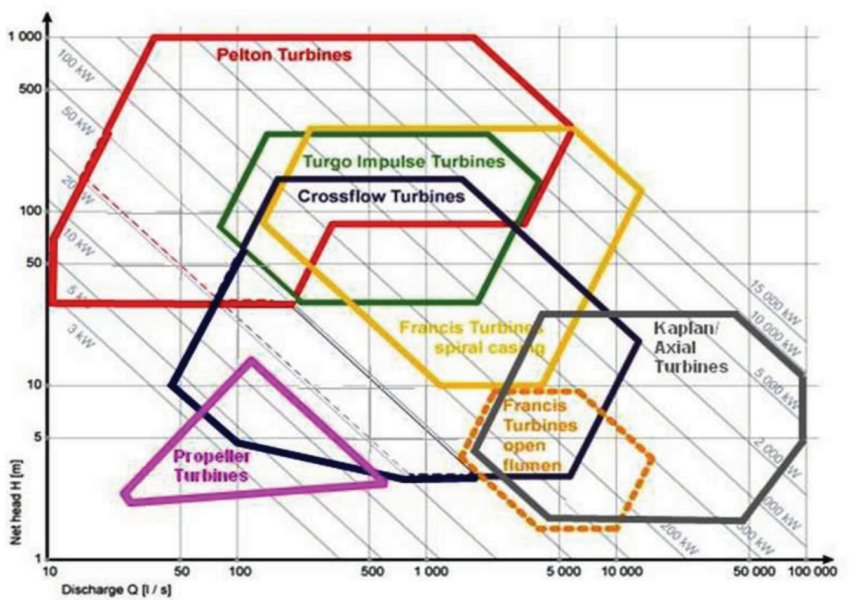

PEEDA, 2009

Figure 1. Positioning of Low Head Pico Hydro Propeller Turbine vis-à-vis Other Turbine Types Available in Nepal.

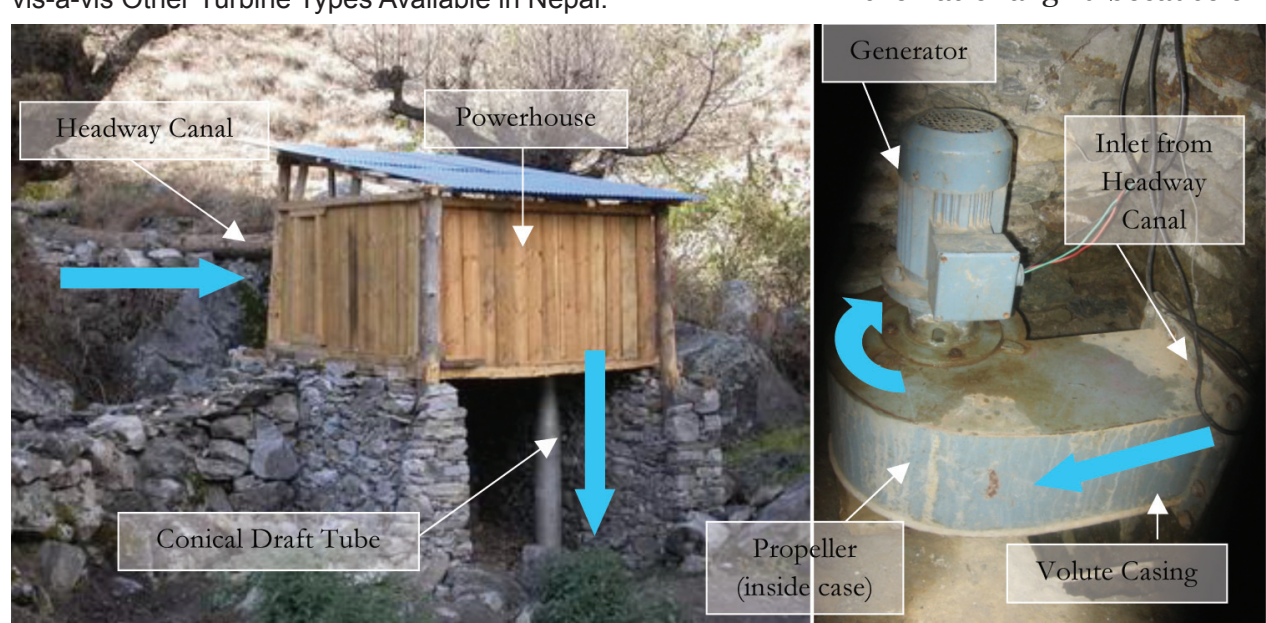

Figure 3. Typical Layout - Water Flow Indicated by Blue Arrows (Left Hand Photo Courtesy of RIDSNepal).

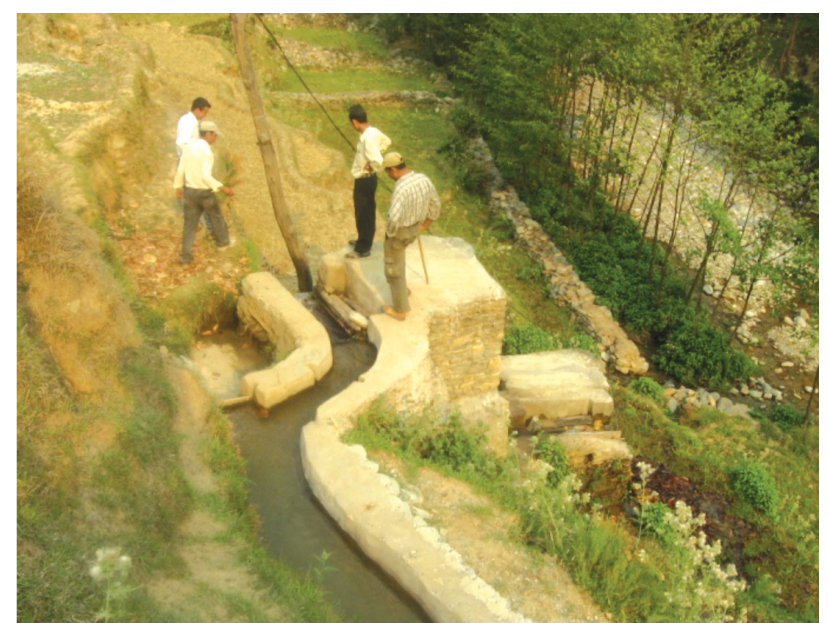

Figure 2. Two Pico-Hydro Low head Turbines in Series, Gulmi.

demand which all together work against economical viability of rural electrification. Social inclusion and the state's responsibility in providing electricity to all its citizens are the major thrusts for rural electrification. Some remote communities with suitable water resources are able to employ micro-hydro installations to produce power, but there are still a large number of communities that neither have the pre-conditions required for a micro hydro scheme (head and flow, investments, relatively dense population) nor are likely to be electrified through the national grid because of the cost involved. 
water mills often pass near homes and can provide a small head to a Pico-hydro plant.

For this type of situation, propeller or cross flow type turbines that run on low head but use larger water volume can be suitable. These technologies would not compete with the irrigation channels and water mill sites, as the irrigation canals and water mills could be used during the day and the Pico-hydro at night to cater to the lighting needs of the households and thereby optimizing the utilization of the water resources available.

The introduction of low head Pico-hydro power units into these communities will not only provide them with electricity, but it will also help to further open the door for development. Small amount of power provided by existing pico units (high head peltric sets) has proved to be part of the solution to the energy imbalance, environmental degradation and a good source of income generation in the hills and mountains of Nepal. In most cases, these high head Pico-hydro units use small volume of flow falling through a substantial height, usually more than 40m, to generate enough power for a small village. Unfortunately, many smaller villages do not have suitable sites for peltric type Pico-hydro units.

\section{Widening the Use}

Starting ten years ago, Nepal Hydro and Electric Limited (NHE), with the help of other partners, developed a low-head, high-flow, and pico propeller turbine unit. The unit underwent operational testing and was modified into a reliable, robust and efficient low-head Pico-hydropower unit. There were some research needs especially in electrical load controller which needs to be addressed before launching these units commercially in the market.

Unfortunately, after manufacturing only 14 units, NHE decided that Pico-hydropower units were no longer part of their core business plan and therefore stopped manufacturing them. People, Energy and Environment Development Association (PEEDA) thus bought the technological rights from NHE with and aim to prevent this technology from dying inside the factory.

Pico-hydro systems are often used in remote areas to supply electrical power to areas with no grid connection. They are usually intended for lighting applications. Self excited induction generators are commonly used due to their inexpensiveness and robustness. However, they are not able to start induction motors easily. It is often maintained that the generator must be rated a factor of five times larger than the motor load to ensure starting. Many Pico-hydro systems are of the size $200 \mathrm{~W}$ to $2 \mathrm{~kW}$. This can be suitable for the lighting applications, but not at present for any industrial applications using motors e.g. electric drilling, wood sawing, sewing machine, etc. This project addresses this issue, and will design the controller system to operate electric machine with Picohydro system.

PEEDA, with its aim and objective, is always looking for the productive use of the small generated power at its maximum. To address the commercial utilization of energy generated from Pico-hydro system, PEEDA recently has developed a new controller in the industrial collaboration with Kathmandu Alternative Power and Energy Group (KAPEG) under Renewable Nepal Program. With the new excitation and control system added, new Electrical Load Controller (ELC) is able to start the drill machine, television, computer and other electronic equipments that require high inrush current to operate. Thus, for the first time, Pico-hydro systems with self excited induction generators can be used to operate income generating power tools and processing equipments.

\begin{tabular}{|l|c|c|c|}
\hline Specification & PT1-Mk2 & PT03-Mk2 & PT5 \\
\hline Generator Output (kW) & 1.2 & 0.3 & 5.0 \\
\hline Design Head (m) & 3.5 & 2.32 & 7.6 \\
\hline Design Flow rate (I/s) & 85 & 30.5 & 110 \\
\hline Output Voltage (V) & 230 & 230 & 230 \\
\hline No. Phases & 1 & 1 & 3 \\
\hline
\end{tabular}

Table 1. Unit Specification and Component Picture.

This Pico-hydro technology can electrify poor electricity lacking communities with green and reliable electrical energy. Despite the initial high cost per $\mathrm{kW}$, the minimal cost required for running the scheme and great potential for it to open up new revenue streams, make the technology not only economically feasible, but also profitable for the poor communities of Nepal. The electrifying of people's homes will reduce their dependence on fossil fuels and traditional biomass, which in turn means that they will not have to spend what little money they have on fossil fuels and they will be able to stop consuming the ever-depleting forest resources. By not having to depend on these fuel sources will also lessen the risk to health posed by the indoor air pollution from these combustible fuels. As it is usually women who are required to collect firewood and then burn it for household uses, through the utilization of this technology, women will be removed from the drudgery and will be empowered to carry out other activities.

\section{Addressing the High Market Demand}

The feasibility study conducted by PEEDA showed that low-head Pico-hydropower system fills a gap in the Nepalese renewable energy market. The field investigations and analyses undertaken proved that investing in a low-head Pico-hydro scheme is a viable and attractive option for poor rural communities and can greatly benefit them. Figures of 2500 such sites are highly suitable for low head Pico units (Jabati 2009). Wide ranges of benefits include socio-economic, financial and environmental gains. The low-head Picohydropower system also provides an opportunity for the current rural/urban and regional energy access disparities in Nepal to be addressed. The low-head Picohydropower system was shown by the study to offer one of the best means by which to supply quality, reliable 
and cost effective power to consumers in scattered and remote rural areas. Feedback from the beneficiaries of the NHE demonstration sites indicated an overall high level of satisfaction and acceptability of low-head picohydropower systems. The study indicated that low-head Pico-hydropower units have a good market potential.

In a nutshell, the low-head Pico-hydropower units can assist poverty reduction and provide environmental sustainability. A community that installs a low-head Picohydro unit can have the facility of lighting and are also able to use the electricity to cook, reducing the reliance on firewood. This improves health of the family, reduces drudgery, provides time for other income generating activities and decreases the number of trees that are cut down hence helping the environment. The units can also be used for income generating activities such as tailoring, saw milling, grain milling, battery recharging and even charging laptop computers. This gives many opportunities for communities to have alternatives to subsistence farming and can reduce the poverty level of a community. As the units are small, they have minimal environmental impacts of their own, and so provide real opportunity for renewable and sustainable energy development in rural communities.
Biraj Gautam, a graduate in Environmental Science from Tribhuvan University, has been associated with PEEDA since last four years in the capacity of Environmental Manager. He is also the coordinator of the Pico-Hydro Promotion Project that PEEDA is currently undertaking. He has been mainly involved in project conceptualization, planning and implementation of various projects in hydropower, solar and biomass technologies. Since the last one year, he had been creating sustainable rural renewable service model based on solar, biogas and biomass in partner organization in India and is in the process of replicating it in Nepal.

Corresponding address: biraj@peeda.net

\section{Reference}

ISRC (Intensive Study and Research Centre), 2008, Village Development Committee Profile of Nepal: A Socio-Economic Development Database of Nepal, ISRC, Kathmandu.

Jabati, M.C., 2009, Pre-feasibility Study for the Promotion of Low-Head Propeller Type Pico Hydropower Technology in Selected Districts of Nepal for the Benefit of Rural Communities, People Energy and Environment Development Association (PEEDA), Kathmandu (unpublished).

\section{CALENDAR OF EVENTS - ENERGY}

Continued from page 63

6-8 November, 2012: Power-Gen Africa. Location: Johannesburg, South Africa. More info: http:// www.powergenafrica.com

6-8 November, 2012: Renewable Energy World Africa sponsored by PennWell Corporation. Location: Johannesburg, South Africa. Contact Email: leec@Pennwell.com. More info: http:// www.powergenafrica.com

7-9 November, 2012: 6th Renewable Energy India 2012 Expo, Theme: International Renewable Energy Expo- Solar Energy, Wind Energy, Small Hydro Power, Bio Energy, Geothermal Energy, and Energy Efficiency. Location: NCR Delhi, India. More info: http://www.renewableenergyindiaexpo.com

11-15 November, 2012: Renewable Energy Congress. Location: Eindhoven, DC, USA. More info: http:// www.osa.org/meetings/optics_and_photonics_ congresses/Renewable_Energy/default.aspx

12-14 November, 2012: 7 th International Renewable Energy Storage Conference \& Exhibition (IRES 2012). Location: Berlin, Germany. Contact Email: IRES@eurosolar.de

12-15 November, 2012: Venice 2012-4th International Symposium on Energy from Biomass and Waste. Location: Venice, Italy. Contact Email: info@eurowaste.it More info: www. venicesymposium.it/

17-18 November, 2012: International Conference on Power and Energy (ICPES 2012). Location: Pune, India. More info: http://www.icpes.org/

19-20 November, 2012: Australian Institute of Energy National Conference. Location: Sydney, Australia. More info: http://www.aie2012.com.au

Nov.22-23, 2012; International Forum on World Economy Development Tendency, the international cooperation with different countries and UN PPP modalities. Location: Xian, China, More info: International Non-Governmental Organization on Renewable Energy; tongjiandong@gmail.com

26-28 November, 2012: People in Energy. Location: Houston, Texas, USA. More info: http://the-tma. org/oilandenergy/

1-31 December, 2012: Closing Event - International Year of Sustainable Energy for All, Theme: Information on exact date and relevant information yet to be determined. Location: New York, USA.

6-7 December, 2012: 3rd Annual Battery Safety. Location: Las Vegas, USA. More info: http:// www.knowledgefoundation.com/viewevents. php?event_id=282\&act=evt

11-13 December, 2012: POWER-GEN International sponsored by PennWell. Location: Orlando, Florida, USA. Contact Email: pgiconference@ pennwell.com. More info: www.power-gen.com

20-22 December, 2012: International Renewable Energy Congress. Location: Sousse, Tunisia. More info: http://www.irec.cmerp.net 